INTERNATIONAL JOURNAL OF RESEARCHES IN BIOSCIENCES, AGRICULTURE AND TECHNOLOGY

(C) VISHWASHANTI MULTIPURPOSE SOCIETY (Global Peace Multipurpose Society) R. No. MH-659/13(N) www.vmsindia.org

\title{
RESPONSE OF SESAME VARIETIES TO DIFFERENT SOWING DATES
}

\author{
D. J. Jiotode ${ }^{1}$, V. S. Khawale ${ }^{2}$, N. K. Sahu ${ }^{3}$ and D. Patel ${ }^{4}$ \\ ${ }^{1}$ Agromet, Agronomy Section, College of Agriculture, Nagpur \\ ${ }^{2}$ Agronomy, Section College of Agriculture, Nagpur \\ ${ }^{3,4}$ P.G.Students, Agronomy Section, College of Agriculture, Nagpur
}

\begin{abstract}
A field experiment entitled on sesame varieties under different dates of sowing was conducted during 2013-2014 at Agronomy farm, college of Agriculture, Nagpur. The component was laid out in split plot design with five sowing dates 26, 27, 28, 29, $30 \mathrm{MW}$ and two varieties replicated three times. Growth contributing characters viz., plant height, number of branches plant ${ }^{-1}$ and dry matter accumulation plant ${ }^{-1}$, were significantly higher in variety AKT64 and found maximum during $2^{\text {nd }}$ sowing date i.e. $27^{\text {th }} \mathrm{MW}$ during all growth stages. Yield contributing characters such as total number of capsules plant ${ }^{-1}$, seed yield plant ${ }^{-1}$, straw yield plant ${ }^{-1}$, seed yield q ha ${ }^{-1}$, straw yield q ha ${ }^{-1}$ and biological yield $\mathrm{q} \mathrm{ha}^{-1}$, were significantly higher when sown in $27^{\text {th }} \mathrm{MW}$, variety AKT-64 recorded significantly higher values for these parameters as compared to variety Western-11. Sowing beyond $28^{\text {th }}$ MW significantly reduced yield of sesame.
\end{abstract}

Keywords: Sesame, sowing dates, variety

\section{Introduction:}

Sesame [Sesamum indicum Linn. (Pedaliaceae)] adorned as "queen of oilseed crop" by virtue of the excellent quality of oil and its use in domestic purpose. It is one of the most important ancient edible crop grown in India next to groundnut and rapeseed-mustard. Sesame seeds are rich source of edible oil, food, nutrition health care and biomedicine. Its oil content generally varies from 48 to 52 per cent and contains $6355 \mathrm{k} \mathrm{cal} \mathrm{kg}^{-1}$ energy in seeds (Kumar and Goel, 1994). The seeds are also rich source of proteins $(20-28 \%)$, sugars $(14-16 \%)$ and minerals $(5-7 \%)$ and nutrients like calcium $(1.31 \%)$ and phosphorus (Dinosa and Gupta, 1993).

India ranks first in area $(45 \%)$ of sesame in the world. The total area of sesame in India during 2012-13 was 17.03 lakh hectares with the total production of 7.48 lakh tones (Anonymous 2012).

India, the major sesame growing states are Uttar Pradesh, Rajasthan, Madhya Pradesh, Andhra Pradesh, Maharashtra, Gujarat, Tamil Nadu and Orissa. In Maharashtra state, area under sesame crop during 2010-2011 was 560 ha with the production of 199 tones and productivity of $355 \mathrm{~kg} \mathrm{ha}^{-1}$. In Vidarbha region, Nagpur and Amravati revenue divisions are the most important sesame growing areas. Yield potential of sesame crop can be exploited by the use of agronomic techniques. Among them standardized agronomic practices required for realizing yield potential of kharif sesame, sowing time and varieties play pivotal role.

It is true that prevalence of congenial weathers conditions is the only factor which neutralizes the good heritable potentiality of a variety under systematic agronomic practices.
Time of sowing and the age of crop are important factor that influenced the yield and quality of the produce.

Now a day, attention also paid on global warming and due to global warming, climatic changes are often observed in India. That's why growth, yield, and oil percentage in sesame is greatly affected. To overcome this problem, there is necessity to study the response of the different varieties of sesame to different sowing time. There is a great scope for increasing the yield of sesame crop substantially by resorting to optimum sowing time is "non cash" input. Therefore it is essential to find out the suitable time of sowing to a particular variety of sesame.

\section{Materials and Methods:}

The field experiment was conducted in field No.9 at Agronomy farm, college of Agriculture, Nagpur during kharif season of 2013-2014. The topography of experimental site was fairly uniform and leveled. The treatment consisting of 5 sowing dates, i.e $26^{\text {th }} \mathrm{MW}, 27^{\text {th }}$ MW, 28 th $\mathrm{MW}, 2^{\text {th }} \mathrm{MW}$ and $30^{\text {th }} \mathrm{MW}$ with two sesame varieties (AKT-64 and Western-11) were sown in split plot design and replicated three times. After seed bed preparation, sowing was done by drilling. Sesame varieties were sown at $30 \mathrm{~cm}$ row to row spacing. The seeds were put in soil approximately@2-3 cm depth. To maintain optimum plant population thinning and gap filling was carried out 10 days after sowing by keeping only one healthy seedling hill-1.

The soil analyzed in experimental site have loamy clayey in texture, medium in nitrogen content, medium in phosphorus and rich in potash. Organic carbon content was medium and soil reaction was slightly alkaline (7.7) in nature. A basal dose of $25 \mathrm{~kg} \mathrm{P}_{2} \mathrm{O}_{5} \mathrm{ha}^{-1}$ 
was applied through single super phosphate, while nitrogen dose @ 40 kg ha-1 was applied through urea in two equal splits doses at sowing and 30 DAS. A basal dose of $25 \mathrm{~kg} \mathrm{P}_{2} \mathrm{O}_{5}$ ha-1 was applied through single super phosphate, while nitrogen dose @ $40 \mathrm{~kg} \mathrm{ha}^{-1}$ was applied through urea in two equal splits doses at sowing and 30 DAS. The total rainfall during crop growth period i.e. June 2013 to October, 2013 was $1403 \mathrm{~mm}$ received in 50 rainy days. Observations were recorded on plant height $(\mathrm{cm})$, branches plant ${ }^{-1}$, dry matter accumulation plant ${ }^{-1}$, number. of capsule plant $^{-1}$, seed yield plant ${ }^{-1}$, straw yield plant ${ }^{-1}$, seed yield $\mathrm{q}$ ha1 , straw yield $\mathrm{q} \mathrm{ha} \mathrm{h}^{-1}$ and biological yield $\mathrm{q} \mathrm{ha}^{-1}$

\section{Results and Discussion: \\ Effect of sowing dates}

Sowing dates significantly influenced the different growth characters (Table 1) viz., plant height, number of branches plant ${ }^{-1}$ and dry matter accumulation plant ${ }^{-1}$. All the above growth characteristics were significantly higher when sown during 27th $\mathrm{MW}$ during all growth stages. Similar results were reported by Sarkar et al. (2007). They also reported that sowing dates significantly influenced number of branches plant ${ }^{-1}$ and dry matter accumulation.

As regard to different yield contributing characters of sesame (Table 1) viz, total number of capsule plant $^{-1}$, seed yield plant ${ }^{-1}$, straw yield plant $^{-1}$, seed yield $\mathrm{ha}^{-1}$, straw yield $\mathrm{ha}^{-1}$ and biological yield ha $\mathrm{h}^{-1}$ were significantly highest during sowing in $27^{\text {th }} \mathrm{MW}$ as compared to sowing in $26^{\text {th }}, 27^{\text {th }}, 28^{\text {th }}, 2^{\text {th }}$ and $30^{\text {th }} \mathrm{MW}$. Highest sesame seed yield of $9.52 \mathrm{q} \mathrm{ha}^{-1}$ was recorded when sown in $27^{\text {th }} \mathrm{MW}$ and it was significantly higher as compared to sowing of sesame in rest of the MW. Similar to this result Abdel Rehman et al. (2007), also found that sowing dates significantly affected number of plant $\mathrm{m}^{-2}$, number of branches, number of capsule plant-1, 1000 seed weight and seed yield. The highest yield was recorded for early July sowing by Shuhak genotype. Similarly Olowe (2007) reported that two cultivars of sesame Yandev-55 and E-8 produced maximum grain yield when sown in early July and late July respectively. Rammohan and Sivagamy (2012) inferred from their study that performance of sesame variety KS-95010 was superior when sown early during the second fortnight of February under irrigated condition in the Cauvery delta zone.

\section{Effect of varieties}

In respect of growth attributing characters, variety AKT-64 attained higher height $(116.27 \mathrm{~cm})$ than Western-11 (115.27 $\mathrm{cm})$. AKT-64 possessing higher number of branches plant ${ }^{-1}(7.66)$ and higher dry matter accumulation plant $^{-1}(42.80 \mathrm{~g})$ as compare to variety Western-11.

Significantly higher seed yield plant $^{-1}$ (3.95 g) and seed yield ha-1 (885 qha $^{-1}$ ) was recorded by variety AKT-64 as compared to Western-11. Higher seed yield in AKT-64 is attributed to higher number of capsule plant ${ }^{-1}$ and higher value of other growth characters. Similar to this result Kadam (2001) reported that AKT-101 to be good in respect of growth parameters, yield contributing characters, utilization of applied fertilizers, oil content and yield. Korhale (2010) evaluated the varietal performance of sesame with cultivars Phule Til-1 and AKT-101. Cultivar AKT-101 recorded better growth and yield attributing characters with oil content over Phule Til-1 variety. Patil (2012) also studied the response of sesame with cultivars Phule Til-1, AKT-101, JLT-7 and Padma under summer condition and reported that AKT-101 showed better growth and yield attributing characters.

Table 1. Effect of sowing dates and varieties on the yield contributing characters

\begin{tabular}{|c|c|c|c|c|c|c|c|c|c|}
\hline & $\begin{array}{l}\text { Plant } \\
\text { height } \\
(\mathrm{cm})\end{array}$ & $\begin{array}{l}\text { Branches } \\
\text { plant-1 }^{-1}\end{array}$ & $\begin{array}{l}\text { Dry matter } \\
\text { accumulation } \\
\text { plant }^{-1}\end{array}$ & $\begin{array}{l}\text { No. of } \\
\text { capsules } \\
\text { plant-1 }\end{array}$ & $\begin{array}{l}\text { Seed } \\
\text { yield } \\
\text { plant } 1\end{array}$ & $\begin{array}{l}\text { Straw } \\
\text { yield } \\
\text { plant-1 }\end{array}$ & $\begin{array}{l}\text { Seed } \\
\text { yield } \\
\text { q } \text { ha }^{-1} \\
\end{array}$ & $\begin{array}{l}\text { Straw } \\
\text { yield } \\
\text { q ha-1 } \\
\end{array}$ & $\begin{array}{l}\text { Biological } \\
\text { yield } \\
\text { q ha-1 } \\
\end{array}$ \\
\hline \multicolumn{10}{|c|}{ Sowing dates } \\
\hline $\mathrm{D}_{1}-26^{\text {th }} \mathrm{MW}$ & 116.67 & 7.70 & 42.18 & 43.87 & 3.68 & 12.89 & 8.17 & 29.73 & 37.90 \\
\hline $\mathrm{D}_{1}-27^{\text {th }} \mathrm{MW}$ & 118.50 & 7.75 & 42.83 & 44.85 & 4.02 & 14.51 & 9.52 & 33.97 & 43.49 \\
\hline $\mathrm{D}_{1}-28^{\text {th }} \mathrm{MW}$ & 115.67 & 7.60 & 42.80 & 43.33 & 3.66 & 12.69 & 8.00 & 29.62 & 37.62 \\
\hline $\mathrm{D}_{1}-29^{\text {th }} \mathrm{MW}$ & 114.17 & 7.22 & 42.75 & 43.25 & 3.72 & 12.99 & 8.12 & 29.68 & 37.80 \\
\hline $\mathrm{D}_{1-30^{\text {th }}} \mathrm{MW}$ & 113.83 & 7.07 & 42.73 & 42.88 & 3.28 & 12.27 & 7.06 & 26.34 & 33.41 \\
\hline $\mathrm{SE} \pm$ & 0.47 & 0.07 & 0.03 & 0.30 & 0.10 & 0.40 & 0.39 & 1.09 & 1.45 \\
\hline $\mathrm{CD}$ at $5 \%$ & 1.49 & 0.23 & - & 1.00 & 0.31 & 1.31 & 1.27 & 3.56 & 4.37 \\
\hline \multicolumn{10}{|l|}{ Varieties } \\
\hline $\mathrm{V}_{1}-\mathrm{AKT}-64$ & 116.27 & 7.66 & 42.80 & 44.41 & 3.97 & 13.62 & 8.85 & 31.99 & 40.85 \\
\hline $\begin{array}{l}\mathrm{V}_{2} \text {-Western- } \\
11\end{array}$ & 115.27 & 7.27 & 42.77 & 42.86 & 3.38 & 12.52 & 7.49 & 27.74 & 35.23 \\
\hline $\mathrm{SE} \pm$ & 0.30 & 0.06 & 0.02 & 0.34 & 0.08 & 0.25 & 0.22 & 0.69 & 0.88 \\
\hline
\end{tabular}




\begin{tabular}{|l|l|l|l|l|l|l|l|l|l|}
\hline $\mathrm{CD}$ at $5 \%$ & 0.96 & 0.18 & - & 1.08 & 0.24 & 0.79 & 0.68 & 2.17 & 2.79 \\
\hline Interaction & & & & & & & & & \\
\hline $\mathrm{SE} \pm$ & 0.68 & 0.13 & 0.04 & 0.77 & 0.17 & 0.56 & 0.48 & 1.54 & 1.98 \\
\hline $\mathrm{CD}$ at $5 \%$ & - & - & - & - & - & - & - & - & - \\
\hline
\end{tabular}

\section{Effect of interaction}

The interaction effects between sowing times and varieties were non significant for all the traits studied.

\section{References:}

Anonymous, 2012. Annual report 2012-2013, Department of Agriculture and cooperation, ministry of Agriculture, GOI.www.agricoop.nic.in

Abdel Rahman, AEL. Mahadi, Saif Eldin, M.EL- Amin and G. Faish Ahmad, 2007. Effect of sowing dates on the performance of sesame (Sesamum Indicum L.) genotype under irrigated condition in Northern Sudan. African Crop Sci. Conf. Proc. 8: 1943-1946.

Dinosa, K. S. and S. K. Gupta, 1993. Variability in chemical composition of sesame (Sesamum indicum L.). Harayana Agril. Univ. J. Res. 3(4): 197-201.

Kadam, P. K. 2001. Optimum sowing date, phosphorus requirement and varietal performance of kharif sesame. M.Sc.(Agri.) thesis submitted to P.D.K.V., Akola (Maharashtra).

Korhale, J. J. 2010. Response of summer sesame (S. I. L) to varieties and topping management. Unpublished M.Sc.(Agri.) thesis submitted to MPKV Rahuri (Maharashtra).

Kumar, S. and S. C. Goel, 1994. Population dynamics of a pyralid, Antrigastra catalaunalis (Dup.) on sesmum in relation to abiotic factor. J. Ento. Res. 18(1): 61-64.

Olowe, V.I.O. 2007. Optimum planting date for sesame in transition zone of south west Nigeria. Agricultural tropica ET. 40(4): 156-158.

Patil, D. R. 2012. Response of sesame (S.I.L) cultivars under varying sowing dates under summer season. Unpublished M.Sc.(Agri.) thesis submitted to MPKV Rahuri (Maharashtra).

Rammohan, $J$ and $K$. Sivagamy, 2012. Influence of time of sowing and spacing on the growth and yield attributes of sesame. Madras agri. J. 99(4/6):329-331.

Sarkar, M. N., M. Alam Salim, N. Islam and M. M. Rahman, 2007. Effect of sowing dates and time of harvest on the yield and yield contributing characters of sesame (S. I. L) Seed. Int. J. Sustain Crop Prod. 2(6): 31-35. 